\title{
Implementation Flipped Classroom Based Video for Improving Interest Learning of Physics
}

\author{
Neneng Handriani ${ }^{1 *}$, Ishafit ${ }^{2}$ \\ 1,2 Program Pascasarjan Pendidikan Fisika, Universitas Ahmad Dahlan, Indonesia \\ "Korespondensi: nenenghadriani@gmail.com
}

\begin{tabular}{|c|c|}
\hline Info Artikel & \multirow{10}{*}{$\begin{array}{l}\text { Abstract } \\
\text { This study aims to increase students' interest in learning in the application } \\
\text { of the flipped classroom learning model with video media, and the } \\
\text { instruments used are pre-test and post-test questionnaires and } \\
\text { observation sheets for observers. The analysis was carried out by } \\
\text { checking the completeness of the survey, classifying the answers by giving } \\
\text { scores and obtaining the Normalized Gain test results (N-Gain). This } \\
\text { research was conducted at SMP IT ABU BAKAR FULLAY SCHOOL } \\
\text { class VII, with the research method Pre-Experimental designs with the } \\
\text { form One-Gup Pretest-Posttest Design. Based on the results of research } \\
\text { that has been carried out using the video-based flipped classroom model } \\
\text { to increase student learning interest, the results obtained are } 35 \% \text { which is } \\
\text { classified as moderate, seen from the normalized Gain criteria, if there are } \\
\text { results } 30 \leq N \text {-Gain } \leq 70 \text {, then it is in the medium category. }\end{array}$} \\
\hline $\begin{array}{l}\text { Accepted } 29 \\
\text { Agustus } 2020\end{array}$ & \\
\hline $\begin{array}{c}\text { Revised } 11 \\
\text { September } 2020\end{array}$ & \\
\hline $\begin{array}{l}\text { Published } 28 \\
\text { January } 2021\end{array}$ & \\
\hline $\begin{array}{l}\text { Keywords: } \\
\text { Flipped classroom; } \\
\text { physics learning, } \\
\text { learning video, } \\
\text { learning interest }\end{array}$ & \\
\hline (c) 2020 Universitas & \\
\hline $\begin{array}{c}\text { Muhammadiyah } \\
\text { Buton }\end{array}$ & \\
\hline Under the license & \\
\hline $\begin{array}{l}\text { CC BY-SA } 4.0 \\
\text { (с) (†) }\end{array}$ & \\
\hline$U_{B Y}$ & \\
\hline
\end{tabular}

\section{Introduction}

Physics subjects are basic subjects, in junior high or high school (Kawuri \& Fayanto, 2020). In the learning process learning habits will affect learning itself, which aims to gain knowledge, attitudes, skills and skills, including scheduling and implementation, reading and taking notes, repeating learning materials, concentrating and doing assignments (Kawuri et al., 2019). Interests and habits have an essential meaning in increasing or decreasing learning achievement (Siagian, 2015).

Student achievement in a subject depends on interest. Interest is a constant tendency to pay attention to and remember some activities (Siagian, 2015). The 
solution that may be suitable for fostering student interest in learning is choosing the right media and learning model, one of which is the flipped classroom. Learning media is a method, tool, or process used to convey messages from message sources to message recipients that take place in the educational process (Fayanto et al., 2019). Learning media can be differentiated according to their ability to generate stimuli in the senses of sight, hearing, touch, smell and taste, so that in general the characteristics of learning media are that the media can be felt, seen, heard, and observed by the five senses (Supardi et al. 2015).

Based on previous research, it shows that the Flipped Classroom learning model has a strong influence in honing student skills and makes students have high awareness and responsibility in participating in learning activities (Pratiwi et al. 2017). Using the Flipped Classroom can help students to learn independently by encouraging them to adjust to their new learning experiences (Kurniawan et al. 2018).

Based on the description that has been explained, flipped classroom learning using video media made by the teacher or videos from YouTube is an interactive learning strategy that can be provided by educators by minimizing the amount of direct instruction in their teaching practice while maximizing interaction with each other through video learning (Rohmah et al. 2019). So from this description, the writer is interested in trying to use the video-based flipped classroom as a physics learning material. This aims to be able to develop student interest in learning. The problem limitation in this study is limited to learning importance. This is because this study is a researcher's initial study before entering a broader implementation stage.

\section{Method}

This study uses pre-experimental designs with the form of One-Gup PretestPosttest Design (Fitrianingsih \& Musdalifah, 2015This design uses a pretest before being given treatment, and then the results are compared with the posttest results after being delivered. The type of data collected in this study is quantitative data obtained through questionnaires and observation sheets as research instruments. The purpose of this research is:

1. Explain video-based flipped classroom to increase interest in learning in physics subjects.

2. Explain the feasibility level of the video-based flipped classroom to increase interest in learning in physics subjects.

\subsection{Method of Analysis}

The method used is to find the posttest score of the questionnaire filled in by each student then subtract the pretest score from the questionnaire each student has filled in. After getting the results then divided by the maximum score obtained by multiplying the maximum rating of the survey by the number of questionnaire items, after getting the results, the next time is reduced by pretest and divided by $100 \%$ then averaged. The population in this study was class VII semester 1 , amounting to 22 students. The sample was taken using a total sampling technique considering that the number of students was 22 people because if it were less than 100 , it would be better to take all. To determine the level of interest in learning, the following table of N-Gain criteria. 
Table 1. Criteria for Normalized Gain

\begin{tabular}{cc}
\hline Percentage & Classification \\
\hline $\mathbf{N}-$ Gain $>70$ & High \\
\hline $\mathbf{3 0} \leq \mathrm{N}-$ Gain $\leq$ & Moderate \\
$\mathbf{7 0}$ & \\
\hline $\mathrm{N}-$ Gain $<30$ & Low \\
\hline
\end{tabular}

\subsection{Retrieval of data .}

The data collection stage :

1. Researchers distribute pretest and posttest questionnaires to the students being taught.

2. Distribute the observation sheet to subject teachers as observers.

The above stage is to obtain the data needed to be analyzed to get the results of student learning interest and the suitability of teaching researchers using a flipped classroom. Following are the steps in data analysis:

1. I am checking the completeness of the questionnaire in the form of the integrity of the questionnaire sheet and data that has been filled in by the respondents.

2. Classify the answers by giving a score or values that have been determined as the initial benchmark, then tabulating and analyzing them.

3. To obtain Normalized, Gain test results (N-Gain).

Calculating the normalized Gain score based on the formula (Sugiyono, 1998).

$$
\text { Gain }=\frac{\text { Postest Score }- \text { Pretest Score }}{\text { Max Score }- \text { Pretest Score }} \times 100
$$

\section{Discussion}

The flipped classroom is a learning model that combines online learning methods outside the classroom and doing assignments in class (Ubaidillah, 2019). The flipped classroom has a positive effect on students seen from the increase in academic achievement (Herawati et al., 2019). In certain conditions, a flipped classroom is a means. Still, the point is how students can be motivated and active to learn more actively through a learning model that uses technology that is familiar to students in which various materials will be shared before entering the class. It is in the form of video, audio, websites, simulations and others that can simplify the student learning process. That way students will be better prepared to face the material to be taught and be active to convey what they have understood both in questions, statements and discussions with roommates without eliminating the assignment of a teacher in the Classroom (Nurpianti et al. 2018).

In its application, the Flipped Classroom is that the material is first given through learning videos that must be watched by students at their respective homes. In contrast, classroom learning sessions are used for group discussions and working on assignments. Here, the teacher/tutor acts as a coach or adviser. Its application by researchers, distributing pretest questionnaires first, then video learning material to be studied for the next meeting so that students are better prepared to receive subject matter and distribute groups of 5-6 people in one 
group. At a meeting to deliver the material, the researcher/teacher enters the classroom towards the teacher's table while asking students whether the instructional video that was shared has been seen and understood with the position of the student sitting based on the group that has been previously distributed, After that the teacher walks to a centre point in front while giving an initial introduction to the material then throws questions to students to find out to what extent students understand the learning videos that are shared and continued with the content by the teacher. The teacher gives different questions or quizzes to be completed by each group than from each group, and there will be a representative to explain the answer in front.

As long as students present their answers in front of the teacher, the teacher asks other students about their opinion regarding the solution of one of their friends to find out whether other students understand the material well. While working on group assignments, the teacher continues to guide and confirm the appointment given.

Flipped classroom-based learning aims to make knowledge carried out in the classroom more effective. In conventional classroom learning, generally, a lot of time is spent explaining the teaching material. Still, there is very little time for students to analyze the problems given by the teacher (Yulhendri \& Kurniawati, 2019). Based on the results of a review of the application of the flipped classroom learning model, it was found that students who took classes with the flipped classroom learning model obtained better learning outcomes (Maolidah et al. 2017). In the world of education, students who have a high interest in learning will have more energy to carry out learning activities (Simbolon, 2014). Kurnaianto et al. (2019) reported in their study that the Flipped Classroom learning model was effective in improving critical thinking skills, science learning outcomes and student learning motivation, there was a positive influence between learning motivation and critical thinking skills with student science learning outcomes.

Also, the advantages of a flipped classroom are time efficiency, exploration of elaboration can be broader and deeper, the learning process is more exciting, and a stimulus to spur teacher creativity. The weaknesses of the flipped classroom learning model are unsupported facilities and infrastructure, which have the potential to become a burden for teachers, trigger stress on students and extra monitoring and assistance (Wulandari, 2017). Chandra \& Nugroho (2016) wrote that overall, the advantages of the Flipped Classroom method are (1) Students can learn according to the speed of individual absorption. (2) Lecturers can get to know students better. In the class, lecturers can get to know their students individually, because lecturers have more time. (3) The student can prepare various variations of the presentation of lecture materials that can accommodate all students with multiple absorption speeds. (4) For parallel classes, students can see stuff from other courses. Meanwhile, Rindaningsih (2018) reports that the flipped classroom model is an effective strategy in maximizing student responsibility in exploring learning material online so that it supports motivation and interest in producing maximum projects.

The results of the analysis show that the video-based flipped classroom to increase student interest in learning with moderate category results is $35 \%$ seen from the normalized $\mathrm{N}$-gain criteria $30 \leq \mathrm{N}$-Gain $\leq 70$ reasonable classification. 


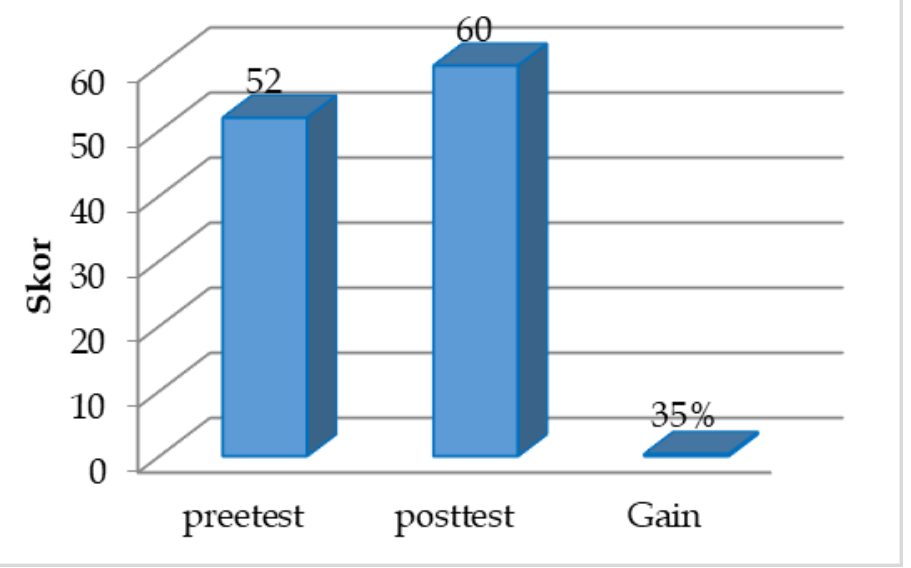

Figure 1. Graph of the pretest and posttest

Figure 1 is the result of each student's interest in learning measured through the pretest and posttest given by the researcher, from the graph above it can be seen that the increase in student interest in education is low because of student learning habits, the closeness between researchers or teachers and students is less and the ability of a researcher. Or the teacher in delivering the material. The learning objectives that have been achieved are:

1. This learning model can make it easier for students to learn and is not limited to learning time

2. The application of video-based flipped classrooms to increase student interest in learning is classified as moderate, namely $35 \%$

One's interest in lessons can be seen from the tendency to pay more considerable attention to these lessons. In addition to learning models and learning media that can increase interest in learning, the ability of a teacher to teach and make students feel happy when receiving material has its benefit for students in this learning and encourages investment in learning to learn.

In textbooks and the factors that influence it states that: "Interest is a feeling of preference and a sense of attachment to something or activity, without being asked". Interest is the acceptance of a relationship between oneself and something outside of oneself which can be a person, an object, a situation, an activity and so on. This interest can increase to a greater extent if the relationship is more durable and closer (Siagian, 2015). In his book, Educational Psychology states "Interest means a tendency and high excitement or a great desire for something." If someone already has a great desire for something, he will do anything.

\section{Conclusion}

Based on the elaboration of the discussion that has been described, a flipped classroom is learning that "reverses" the traditional method, which is usually given in class and students do assignments at home. This learning model can make it easier for students to learn and is not limited to learning time, students can prepare themselves with the material to be studied through the instructional videos that have been shared by the teacher first, this is expected to increase student interest in learning because right video media made by teachers and from youtube are no stranger to students. The results of the research obtained were the students 
'interest in learning at SMP IT ABU BAKAR FULLDAY SCHOOL class VII after the implementation of video-based flipped classrooms to increase students' interest in learning was classified as moderate, namely $35 \%$.

\section{References}

Chandra, F. H., \& Nugroho, Y. W. (2016). Peran teknologi video dalam flipped classroom. Dinamika Teknologi, 8(1), 15-20.

Fayanto, S., Misrawati, M., Sulisworo, D., Istiqomah, H. F. N., \& Sukariasih, L. (2019). The implementation of multimedia on physics learning based on direct instruction model in the topic of light. Indonesian Journal of Learning Education and Counseling, 1(2), 124-132.

Fitrianingsih, R., \& Musdalifah, M. (2015). Efektivitas Penggunaan Media Video Pada Pembelajaran Pembuatan Strapless Siswa Kelas Xii Smk Negeri 1 Jambu. Fashion and Fashion Education Journal, 4(1).

Herawati, R., Sulisworo, D., \& Fayanto, S. (2019).The Development of Learning Videos on PowToon-based Work and Energy Topics to Support Flipped Classroom Learning. IOSRJournal of Research \& Method in Education(IOSRJRME), 9(4), 51-58.

Kawuri, M. Y. R. T., Ishafit, I., \& Fayanto, S. (2019). Efforts to improve the learning activity and learning outcomes of physics students with using a problembased learning model. IJIS Edu: Indonesian Journal of Integrated Science Education, 1(2), 105-114.

Kawuri, M. Y. R. T., \& Fayanto, S. (2020). Penerapan Model Discovery Learning Terhadap Keaktifan dan Hasil Belajar Siswa Kelas X MIPA SMAN 1 Piyungan Yogyakarta. Jurnal Penelitian Pendidikan Fisika, 5(1), 1-8.

Kurnianto, B., Wiyanto, W., \& Haryani, S. (2019). Critical Thinking Skills and Learning Outcomes by Improving Motivation in the Model of Flipped Classroom. Journal of Primary Education, 8(6), 282-291.

Kurniawan, F. H., Setyosari, P., \& Ulfa, S. (2018). Sistem Pembelajaran Berbasis Flipped Classrom Menggunakan Media Lsn Berbasis Flipped Classroom Dengan Media Lsn (Learning Social Network) Siswa Sman 1 Plosoklate. Jinotep (Jurnal Inovasi dan Teknologi Pembelajaran): Kajian dan Riset Dalam Teknologi Pembelajaran, 3(2), 130-136.

Maolidah, I. S., Ruhimat, T., \& Dewi, L. (2017). Efektivitas Penerapan Model Pembelajaran Flipped Classroom pada Peningkatan Kemampuan Berpikir Kritis Siswa. Educational Technologia, 1(2).

Nurpianti, S., Suwarna, I. R., \& Jauhari, A. (2018). Kajian Implementasi Pendekatan Flipped Classroom pada Pembelajaran Fisika. ProsidingSeminar NasionalFisika (SINAFI). Bandung.

Pratiwi, A., Sahputra, R., \& Hadi, L. (2017). Pengaruh model flipped classroom terhadap self-confidence dan hasil belajar siswa SMAN 8 Pontianak (Doctoral dissertation, Tanjungpura University).

Rindaningsih, I. (2018). Efektifitas model flipped classroom dalam mata kuliah perencanaan pembelajaran prodi S1 PGMI UMSIDA. Proceedings of the ICECRS, 1(3). 
Rohmah, I. I. T., Saleh, M., \& Faridi, A. (2019). Penerapan Model Pembelajaran Flipped Classroom Berbasis Weblog Pada Kelas Content And Language Integrated Learning (CLIL).

Siagian, R. E. F. (2015). Pengaruh minat dan kebiasaan belajar siswa terhadap prestasi belajar matematika. Formatif: Jurnal IImiah Pendidikan MIPA, 2(2).

Simbolon, N. (2014). Faktor-faktor yang mempengaruhi minat belajar peserta didik. Elementary School Journal Pgsd Fip Unimed, 1(2).

Sugiyono, A. (1998). Pengantar Evaluasi Pendidikan (Pendekatan Kuantitatif, Kualitatif dan R \& D), Bandung : PT. Rineka Cipta.

Supardi, S. U., Leonard, L., Suhendri, H., \& Rismurdiyati, R. (2015). Pengaruh media pembelajaran dan minat belajar terhadap hasil belajar fisika. Formatif: Jurnal IImiah Pendidikan MIPA, 2(1).

Ubaidillah, M. (2019). Penerapan Flipped Classroom Berbasis Teknologi Informasi pada Mata Pelajaran Fiqih di MTs Al-Chusnaniyah Surabaya. Islamika: Jurnal IImu-IImu Keislaman, 19(01), 34-45.

Wulandari, H. (2017). Optimalisasi E-learning Dengan Menggunakan Metode Flipped classroom.

Yulhendri, Y., \& Kurniawati, T. (2019). Flipped Learning Berbasis Web Pada Pembelajaran Di Universitas Negeri Padang. 